\title{
Review of Information and Communication Technology Devices for Monitoring Functional and Cognitive Decline in Alzheimer's Disease Clinical Trials
}

\author{
Jagan A. Pillai MBBS, PhD* and Aaron Bonner-Jackson, PhD \\ Departments of Neurology and Lou Ruvo Center for Brain Health \\ Cleveland Clinic, Cleveland, $\mathrm{OH}, \mathrm{USA}$
}

Submitted July 2014. Accepted for publication December 2014.

\begin{abstract}
Detecting and monitoring early cognitive impairment in Alzheimer's disease (AD) is a significant need in the field of AD therapeutics. Successful AD clinical trial designs have to overcome challenges related to the subtle nature of early cognitive changes. Continuous unobtrusive assessments using Information and Communication Technology (ICT) devices to capture markers of intra-individual change over time to assess cognitive and functional disability therefore offers significant benefits. We review the literature and provide an overview on randomized clinical trials in $\mathrm{AD}$ that use intelligent systems to monitor functional decline, as well as strengths, weaknesses, and future directions for the use of ICTs in a new generation of AD clinical trials.
\end{abstract}

Keywords: Alzheimer's disease, clinical trials, embedded devices, intelligent systems, smart devices, information and communication technologies

\section{INTRODUCTION}

It is estimated that there are nearly 7.7 million new cases of dementia each year worldwide, implying one new case every 4 seconds [1]. Alzheimer's disease (AD) as a cause accounts for an estimated 60 to $80 \%$ of dementia cases. A combination of biomarkers (cerebrospinal fluid, brain imaging) along with clinical and cognitive assessment is used to identify patients with $\mathrm{AD}$. Currently, there are no available treatments that can stop or reverse $\mathrm{AD}$ progression to dementia. It is increasingly recognized that changes related to $\mathrm{AD}$ predate the stage of dementia by more than a decade among subjects with autosomal dominant mutations [2], and an extended predementia stage of AD is likely also present among individuals who develop sporadic $\mathrm{AD}$. There is significant interest therefore in identifying factors through the life span that relate to later cognitive decline. Pre-dementia states including Mild Cognitive

*Corresponding Author: Jagan A Pillai, Lou Ruvo Center for Brain Health, Cleveland Clinic, 9500 Euclid Ave/U10, Cleveland, OH 44195. Tel: (216) 636 9467. Fax: (216) 445 7013. E-mail: pillaij@ccf.org. Other author: BONNERA3@ccf.org. 
Impairment (MCI), where early cognitive changes are more subtle, are therefore a focus for renewed clinical trial effort to prevent or delay progression to dementia [3]. Methods to monitor early subtle cognitive changes are therefore of significant interest.

Current methods for cognitive assessment among subjects in AD clinical trials are constrained by two major limitations. First, cognitive assessments are administered at discrete intervals, and rely on self-report and recall of events from people who often are memory impaired. Contextual aspects of a subject's daily life that might affect performance are not captured, and as a result, data collected are brief snapshots that do not always reflect real world situations (lacking ecological validity) [4, 5]. Second, there is often only a small difference among cognitive test results between control and patient groups as the degree of cognitive decline is often not dramatic in early stages of $\mathrm{AD}$. Larger numbers of subjects are therefore needed in a pre-dementia clinical trial for noting any change in cognition over reasonable time duration.

A challenge in the AD field has been developing economically efficient ways of detecting changes in cognition and function very early in $\mathrm{AD}$. The aim of this review is to provide a narrative survey of the literature on the use of ICT devices as an alternate data collection strategy for clinical trials in pre-dementia AD in helping overcome challenges in measuring subtle early cognitive and functional decline reliably. We review the literature on current use of ICT devices in AD clinical trials and address future directions on the role that ICT plays in this field.

\subsection{Measuring Cognitive Change in Pre-Dementia Stages of AD By Traditional Neuropsychology}

In traditional neuropsychology evaluations, it is often difficult to establish the patient's premorbid level of functioning (i.e., a baseline) without prior test results. This is a particularly challenging issue as we move towards the ends of the cognitive spectrum. For example, a very highly functioning individual may show relative declines in memory or other cognitive difficulties but continue to perform in the average range relative to same-aged peers. Similarly, it may be difficult to detect a relative decline in individuals with lifelong cognitive weaknesses or lower intellectual capacity, as their long-standing abilities were likely lower than those of their peers. A practical limiting factor in getting quick baseline and follow up evaluations is the discrete time interval between serial tests needed to avoid practice effects of test taking (repeat tests are usually administered at least 9 months apart). Capturing intra-individual change in cognition within a reasonable time frame is therefore a need that has yet to be succinctly addressed in AD clinical trials by traditional cognitive evaluations.

Likewise, subtle cognitive changes may go undetected by traditional neuropsychological assessment techniques. As AD typically presents with insidious onset and a slowly progressive course, mild cognitive declines that occur very early in the disease process may be indistinguishable from normal cognitive variability or statistical "noise". Additionally, neuropsychological measures are often insensitive to behavioral changes that may manifest as part of a neurological syndrome. For example, individuals with suspected frontotemporal lobar degeneration (FTLD) or a frontal variant of $\mathrm{AD}$ are often fairly cognitively intact in early stages of the disease, despite 
the presence of prominent behavior changes that are often highly disruptive and may result in functional impairment. Early behavioral changes associated with onset of Alzheimer's disease (e.g., confusion in novel settings, decreased initiative related to apathy) may be diagnostically informative and may be described during the clinical interview, although they are obviously difficult to capture and monitor over time through typical neuropsychological assessment methods.

\subsection{Using ICT Devices to Capture Functional Decline in a Pre-Dementia Population}

Multiple cross-sectional studies have found correlation between cognitive status and functional disability in older individuals [6-8]. Some have noted that functional decline over time and functional status predicts cognitive decline over time in older adults over age 75 [9]. Dementia, (the end stage of impairment in many neurodegenerative conditions) is distinguished clinically from an earlier stage of MCI by functional impairment in daily activities which represents a decline from previous level of performance [10]. Use of ICT systems is a potentially tractable way to capture ubiquitous data about subtle functional decline (and thereby serving as a predictor for early cognitive decline or as a marker for the dementia stage) without time sensitive intervals between tests. Portable and wearable sensors are commercially available that are low cost and reliable in monitoring heart rate, walking pace, distance covered, calories burned and other activities. These systems could help collate baseline (or premorbid) data on functional abilities of a person by continuous measurement of everyday activities and thereby overcome the discrete time interval limitations between serial tests for traditional neuropsychology testing. These systems could therefore impact the two major limitations affecting cognitive and functional evaluations among subjects in $\mathrm{AD}$ clinical trials:time duration of study and subject number limitations.

Methods to directly assess daily performance of activities that are related to cognitive function ("everyday cognition") are of increasing interest and were the focus of a National Institute on Aging (NIA) and Alzheimer's Association convened workshop "Cognitive Assessment of Early Dementia" [4] and the Monaco Clinical Trials on Alzheimer's Disease (CTAD) expert meeting [5]. Even though there is an extensive literature and pilot data on ICT devices across all age groups, the focus of this review is on their use in a memory impaired population. Error mitigation and assessing the quality of tasks performed within a patient's daily functional routine or inherent to the medical environment have been the focus of efforts in developing home monitoring systems in the dementia population (See Table1), while the use of ICT devices in longitudinal monitoring of cognitive changes in $\mathrm{AD}$ clinical trials has a different emphasis with accurate reproducible measures that correlate with neuropsychological function.

For $\mathrm{AD}$ clinical trials, the focus is on developing objective correlates of just noticeable differences [18] (the disparity between particular observed responses detected on $50 \%$ of occasions over the period of study in this scenario) that are meaningful to an individual's functional skills. These are often at present reported to the physician or neuropsychologist but cannot be adequately captured for use in standardized tests for diagnosis or developing effective interventions. 
74 Review of Information and Communication Technology Devices for Monitoring Functional and Cognitive Decline in Alzheimer's Disease Clinical Trials

Table 1. ICT devices that have undergone pilot testing in a memory impaired population.

\begin{tabular}{|c|c|c|c|c|c|}
\hline $\begin{array}{l}\text { Study } \\
\text { number }\end{array}$ & $\begin{array}{c}\text { Authors } \\
\text { [Reference] }\end{array}$ & Technology used & $\begin{array}{c}\text { Domain } \\
\text { monitored }\end{array}$ & $\begin{array}{l}\text { Number of } \\
\text { subjects } \\
\text { (number of } \\
\text { cognitively } \\
\text { impaired } \\
\text { subjects) }\end{array}$ & $\begin{array}{l}\text { Evaluation } \\
\text { scales }\end{array}$ \\
\hline 1. & $\begin{array}{c}\text { Alwan } \\
\text { et al., } 2006[11]\end{array}$ & $\begin{array}{l}\text { System } \\
\text { Components: } \\
\text { (a) PC-Based Data } \\
\text { Manager, } \\
\text { (b) Radio Receiver, } \\
\text { (c) Bed Sensor } \\
\text { System, } \\
\text { (d) Pneumatic Bed Pad, } \\
\text { (e) Wireless } \\
\text { Motion Sensors, } \\
\text { (f) Kitchen Motion } \\
\text { Sensor } \\
\text { with integrated } \\
\text { stove-top } \\
\text { Temperature } \\
\text { Sensor }\end{array}$ & $\begin{array}{l}\text { Activities of daily } \\
\text { living monitoring }\end{array}$ & 22 & $\begin{array}{l}\text { Satisfaction With } \\
\text { Life Scales (SWLS), } \\
\text { modified Caregiver } \\
\text { Strain Index (CSI) } \\
\text { and Caregiver } \\
\text { Burden Interview } \\
\text { (CBI) instruments. }\end{array}$ \\
\hline 2. & $\begin{array}{c}\text { Suzuki et al., } \\
2007 \text { [12] }\end{array}$ & $\begin{array}{l}\text { Passive infrared } \\
\text { movement } \\
\text { sensors }\end{array}$ & $\begin{array}{l}\text { Sleep monitoring } \\
\text { and outdoor visits }\end{array}$ & 14 & MMSE scores \\
\hline 3. & $\begin{array}{l}\text { Hayes et al., } \\
2008 \text { [13] }\end{array}$ & $\begin{array}{l}\text { infrared motion } \\
\text { detectors, } \\
\text { magnetic door } \\
\text { sensors }\end{array}$ & Activity & 14 (7 MCI) & $\begin{array}{l}\text { Walking time and } \\
\text { speed and daily } \\
\text { activity patterns }\end{array}$ \\
\hline 4. & $\begin{array}{c}\text { Hayes et al., } \\
2009 \text { [14] }\end{array}$ & $\begin{array}{l}\text { Electronic pill } \\
\text { box }\end{array}$ & $\begin{array}{l}\text { Medication } \\
\text { adherence }\end{array}$ & 38 (18 MCI) & $\begin{array}{l}\text { Total and regimen } \\
\text { adherence }\end{array}$ \\
\hline 5. & $\begin{array}{l}\text { Kearns et al., } \\
2011[15]\end{array}$ & Tele surveillance & Spatial navigation & $\begin{array}{c}25(14 \\
\text { dementia) }\end{array}$ & $\begin{array}{l}\text { Path tortuosity on } \\
\text { Fractal dimension }\end{array}$ \\
\hline 6. & $\begin{array}{c}\text { Kaye et al, } \\
2013 \text { [16] }\end{array}$ & $\begin{array}{l}\text { Remotely } \\
\text { monitored } \\
\text { computer use }\end{array}$ & Computer use & 113 (38 MCI) & $\begin{array}{l}\text { Time duration of } \\
\text { use }\end{array}$ \\
\hline 7. & $\begin{array}{l}\text { Galambos } \\
\text { et al., } 2013 \text { [17] }\end{array}$ & $\begin{array}{l}\text { Infrared motion } \\
\text { detectors }\end{array}$ & Activity & 5 dementia & $\begin{array}{l}\text { Activity density } \\
\text { maps }\end{array}$ \\
\hline 8. & $\begin{array}{c}\text { Dawadi et al., } \\
2013 \text { [18] }\end{array}$ & $\begin{array}{l}\text { Smart home } \\
\text { activity sensors } \\
\text { (infrared motion } \\
\text { detectors, } \\
\text { magnetic door } \\
\text { sensors) }\end{array}$ & $\begin{array}{l}\text { Instrumental } \\
\text { activities of daily } \\
\text { living }\end{array}$ & $\begin{array}{c}263 \text { (51 MCI, } \\
16 \text { dementia) }\end{array}$ & $\begin{array}{l}\text { Sensor events } \\
\text { tracking activity } \\
\text { subtasks }\end{array}$ \\
\hline 9. & $\begin{array}{l}\text { Hayes et al., } \\
2014 \text { [19] }\end{array}$ & $\begin{array}{l}\text { Wireless passive } \\
\text { infrared motion } \\
\text { sensors }\end{array}$ & Sleep & 45 (16 MCI) & $\begin{array}{l}\text { Multiple measures } \\
\text { of sleep activity }\end{array}$ \\
\hline
\end{tabular}




\section{METHODS}

We reviewed the literature for AD clinical trials that use ICT devices to monitor functional and cognitive changes, particularly to capture functional markers to complement traditional neuropsychological testing. Studies of pharmacological and non-pharmacological interventions were included covering the entire spectrum of cognitive impairment (both pre-dementia and dementia stages) of AD. The goal of this review is to assess the state and maturity of the AD clinical trials that use ICT devices, beyond those pilot trials using ICT devices (see Table 1).

We searched PubMed, PsycINFO and SCOPUS for studies of clinical trials with AD patients using the following search terms: 1. "Alzheimer's disease" or "dementia" or "Mild cognitive impairment" or "predementia"; 2."information and communication technologies" or "actigraphy" or 'assistive technologies' or 'monitoring devices' or 'ICT devices' OR 'infra-red tracking' or 'smart environments'; 3. "Clinical trials". All titles and abstracts that were search hits from January 1995 to September 1, 2014 were reviewed to eliminate studies that did not pertain to our topic of interest. During the course of this review, it was noted that most studies that use ICTs were not captured by our keywords. One possible reason is that over the years the keywords describing ICT devices have varied. In some cases even when an ICT was used as part of a clinical trial (e.g., home monitoring, smart environments, machine learning, etc.), they were not specified in the keywords. Reference lists of relevant articles were therefore also reviewed to identify additional studies. In light of this fact, the current review is not a systematic survey of all articles on this topic.

Articles included for final review met the following criteria: 1) The study primarily evaluated a patient-related outcome in a clinical trial that used measures obtained from an assistive or monitoring technology-related device. 2) The study was a randomized controlled trial (RCT) with a placebo arm; 3) Inclusion and exclusion criteria were specified. 4) Adequate description of the clinical measures being evaluated was reported. 5) Cognitive measures were included as primary or secondary outcomes. 6) The study was reported in English. This review therefore does not cover use of ICT devices in a dementia population not in an RCT.

\section{RESULTS}

RCT studies using ICT devices to monitor outcome measures are listed in Table 2. Fourteen studies from 1995 to September 1, 2014 met our criteria. All studies that targeted AD subjects were focused on the dementia stage of the disease. The numbers of subjects in the trials ranged from very small pilot studies with 16 subjects [20] to larger ones with 157 subjects [22] (median 43.5 subjects/trial). All RCTs we reviewed that used a technology-based measure of functional change were limited to the use of actigraphy. One study successfully used actigraphy to quantify motor agitation in a medication trial [28] as a pilot study while all the other studies used actigraphy measures to quantify rest-activity rhythm and sleep. Additional RCTs were identified that propose to use or are currently using an ICT device to capture longitudinal patient data without final results. A pedometer and an actiwatch were used to monitor activity levels for a week to evaluate the impact of physical exercise on the progression of 
76 Review of Information and Communication Technology Devices for Monitoring Functional and Cognitive Decline in Alzheimer's Disease Clinical Trials

Table 2. Randomized control trials in AD patients using ICT devices for outcome measures

\begin{tabular}{|c|c|c|c|c|c|}
\hline $\begin{array}{l}\text { Study } \\
\text { number }\end{array}$ & $\begin{array}{c}\text { Authors } \\
\text { [Reference] }\end{array}$ & $\begin{array}{c}\text { N, } \\
\text { Population }\end{array}$ & $\begin{array}{c}\text { Duration of ICT } \\
\text { device used }\end{array}$ & $\begin{array}{c}\text { Outcomes } \\
\text { measured using } \\
\text { ICT device }\end{array}$ & Comments \\
\hline 1. & $\begin{array}{l}\text { Scherder et al., } \\
1999[20]\end{array}$ & $16, \mathrm{AD}$ & 6 weeks & $\begin{array}{l}\text { Rest-activity } \\
\text { rhythm }\end{array}$ & $\begin{array}{l}\text { Transcutaneous electrical } \\
\text { nerve stimulation improved } \\
\text { rest-activity rhythm. }\end{array}$ \\
\hline 2. & $\begin{array}{l}\text { Ancoli-Israel } \\
\text { et al., } 2002[21]\end{array}$ & $77, \mathrm{AD}$ & 15 days & $\begin{array}{l}\text { Nighttime sleep } \\
\text { quality, } \\
\text { daytime } \\
\text { alertness, and } \\
\text { circadian } \\
\text { activity } \\
\text { rhythm } \\
\text { parameters }\end{array}$ & $\begin{array}{l}\text { No improvements in nighttime } \\
\text { sleep or daytime alertness in } \\
\text { any of the treatment groups } \\
\text { with morning bright light. }\end{array}$ \\
\hline 3. & $\begin{array}{l}\text { Singer et al., } \\
2003[22]\end{array}$ & $157, \mathrm{AD}$ & 2 months & $\begin{array}{l}\text { Nocturnal } \\
\text { total sleep time }\end{array}$ & $\begin{array}{l}\text { Melatonin had no effect on } \\
\text { nocturnal sleep time. }\end{array}$ \\
\hline 4. & $\begin{array}{l}\text { Dowling et al., } \\
2005[23]\end{array}$ & $46, \mathrm{AD}$ & 10 weeks & $\begin{array}{l}\text { Rest-activity } \\
\text { rhythm }\end{array}$ & $\begin{array}{l}\text { Morning bright light exposure } \\
\text { did not induce an overall } \\
\text { improvement in measures of } \\
\text { sleep or the rest-activity }\end{array}$ \\
\hline 5. & $\begin{array}{l}\text { Dowling et al., } \\
2005[24]\end{array}$ & $70, \mathrm{AD}$ & 10 weeks & $\begin{array}{l}\text { Rest-activity } \\
\text { rhythm }\end{array}$ & $\begin{array}{l}\text { One hour of bright light } \\
\text { exposure did not induce an } \\
\text { overall improvement in } \\
\text { measures of sleep or the rest- } \\
\text { activity. }\end{array}$ \\
\hline 6. & $\begin{array}{l}\text { Ancoli-Israel } \\
\text { et al., } 2005 \text { [25] }\end{array}$ & $63, \mathrm{AD}$ & 8 weeks & $\begin{array}{l}\text { Sleep } \\
\text { duration }\end{array}$ & $\begin{array}{l}\text { Neither Galantamine nor } \\
\text { Donepezil treatment results in } \\
\text { clinically significant sleep } \\
\text { disturbances. }\end{array}$ \\
\hline 7. & $\begin{array}{l}\text { Scherder et al., } \\
2006[26]\end{array}$ & $20, \mathrm{AD}$ & 6 weeks & $\begin{array}{l}\text { Rest-activity } \\
\text { rhythm }\end{array}$ & $\begin{array}{l}\text { High frequency cranial } \\
\text { electrostimulation appears } \\
\text { ineffective in } \mathrm{AD} \text { subjects }\end{array}$ \\
\hline 8. & $\begin{array}{l}\text { Sloane et al., } \\
2007 \text { [27] }\end{array}$ & $66, \mathrm{AD}$ & 3 weeks & $\begin{array}{l}\text { Hours of } \\
\text { sleep and the } \\
\text { number of } \\
\text { sleep bouts }\end{array}$ & $\begin{array}{l}\text { High-intensity ambient light } \\
\text { therapy in the morning or } \\
\text { throughout the day resulted in } \\
\text { a small but statistically } \\
\text { significant increase in } \\
\text { nighttime sleep minutes. }\end{array}$ \\
\hline
\end{tabular}

(Continued) 


\begin{tabular}{|c|c|c|c|c|c|}
\hline $\begin{array}{l}\text { Study } \\
\text { number }\end{array}$ & $\begin{array}{c}\text { Authors } \\
\text { [Reference] }\end{array}$ & $\begin{array}{c}\mathrm{N}, \\
\text { Population }\end{array}$ & $\begin{array}{c}\text { Duration of ICT } \\
\text { device used }\end{array}$ & $\begin{array}{c}\text { Outcomes } \\
\text { measured using } \\
\text { ICT device }\end{array}$ & Comments \\
\hline 9. & $\begin{array}{l}\text { Mahlberg et al., } \\
2007 \text { [28] }\end{array}$ & $20, \mathrm{AD}$ & 14 days & $\begin{array}{l}\text { Movement } \\
\text { counts } \\
\text { performed } \\
\text { every minute }\end{array}$ & $\begin{array}{l}\text { Actigraphy showed a tendency } \\
\text { towards reduced motor } \\
\text { activity in the Rivastigmine } \\
\text { group but clear benefit on } \\
\text { Neuropsychiatric inventory } \\
\text { scale noted. }\end{array}$ \\
\hline 10. & $\begin{array}{l}\text { Dowling et al., } \\
2008 \text { [29] }\end{array}$ & $50, \mathrm{AD}$ & 10 days & $\begin{array}{l}\text { Rest-activity } \\
\text { parameters }\end{array}$ & $\begin{array}{l}\text { Light treatment alone did not } \\
\text { improve nighttime sleep, } \\
\text { daytime wake, or rest-activity } \\
\text { rhythm }\end{array}$ \\
\hline 11. & $\begin{array}{l}\text { Gehrman et al., } \\
2009[30]\end{array}$ & $41, \mathrm{AD}$ & 15 days & $\begin{array}{l}\text { Sleep } \\
\text { duration }\end{array}$ & $\begin{array}{l}\text { No beneficial effect of } \\
\text { exogenous Melatonin. }\end{array}$ \\
\hline 12. & $\begin{array}{l}\text { Eggermont et al., } \\
2010[31]\end{array}$ & 79, Dementia & 12 weeks & $\begin{array}{l}\text { Sleep efficacy } \\
\text { Night time } \\
\text { restlessness }\end{array}$ & $\begin{array}{l}\text { Walking did not show a } \\
\text { positive effect of physical } \\
\text { activity on sleep disturbances } \\
\text { in mild-to-moderate dementia }\end{array}$ \\
\hline 13. & $\begin{array}{l}\text { Mc Curry et al., } \\
2011[32]\end{array}$ & $132, \mathrm{AD}$ & 2 months & Wake time & $\begin{array}{l}\text { Walking, light exposure, and } \\
\text { their combination are } \\
\text { potentially effective } \\
\text { treatments for improving } \\
\text { sleep }\end{array}$ \\
\hline 14. & $\begin{array}{l}\text { Camargos et al., } \\
2014[33]\end{array}$ & $30, \mathrm{AD}$ & 2 weeks & $\begin{array}{l}\text { Sleep } \\
\text { duration }\end{array}$ & $\begin{array}{l}\text { Noted therapeutic effects of } \\
\text { Trazodone } 50 \mathrm{mg} \text { in } \\
\text { community-dwelling AD } \\
\text { patients }\end{array}$ \\
\hline
\end{tabular}

dementia symptoms in the EXERCISE-ON study [34]. The use of heart rate monitor, activity monitors, and pedometers are gaining more popularity in standardization of compliance in the PROMoTE trial in elderly subjects with cognitive impairment [35], and in a trial for caregivers of AD [36]. GPS tracking is being explored to understand the relationship between measures of mobility and cognition in AD [37].

\section{DISCUSSION}

Our review shows that all RCTs in AD using ICT to monitor outcome measures have targeted AD subjects in the dementia stages of the disease. Even though there are many proof-of-concept studies that have used infrared motion sensors, tele-surveillance, GPS tracking, electronic pill boxes, and speech recorded in natural settings in a dementia population, these devices have surprisingly not been used in RCT trials in AD. In fact, among RCTs in AD, actigraphy and accelerometer recordings which target rest-activity 
and motor agitation were the most commonly used ICT devices. Actigraphy was the most commonly used technology targeting rest-activity patterns, although there was one study that noted its usefulness in measuring agitation. Actimetry sensors are unobtrusive and noninvasive devices for monitoring rest/activity cycles and movement worn on the body. Daily actigraphy recording for just 10 days using wrist monitors which recorded movements 24 hours/day, demonstrated an association with the rate of global cognitive decline [38]. Actigraphy is commonly used as an intermittent measure usually during sleep. Its use only during sleep could be a limitation, as the data collected do not necessarily reflect longer term changes. Nevertheless, actigraphy has been employed in some longer clinical trials, e.g., for measuring 4-7 day changes of circadian activity [39].

Even though pilot trials using ICT devices in memory impaired subjects have been extensive and have established a clear proof of principle on their effectiveness in capturing relevant data, they have not made a significant crossover to AD-medicationrelated clinical trials. Compared to ICT (actigraphy) devices reviewed that have already been used in $\mathrm{AD}$ trials, the present generation of ICT devices under development do have the advantages of monitoring longitudinal data for long periods of time and combining multiple sensors (heart rate monitor, activity monitors, and pedometers) to corroborate data across multiple physical and functional domains.

Even though our survey of ICT literature took a systematic approach to reviewing the studies and distinguishing the role of ICT devices in RCTs, it faced a significant hurdle in identifying relevant ICTs in the literature, as the vocabulary of what constitutes the use of an ICT device in a clinical trial often is not easily identifiable. For example, the use of a pedometer or heart rate monitor in the study design is often not distinguishable by a keyword or title search. It is, therefore, possible our review has missed some RCTs where similar devices were used.

\subsection{Challenges in Use of ICT Data in AD Clinical Trials}

Pilot studies using ICT devices have been reported in relation to detecting early dementia (see Table 1), but they are still underutilized in AD clinical trials. ICT devices could help collect patient-centered data in a less demanding fashion from the point of view of the subject, and therefore could decrease subject noncompliance and drop off. Early focus group evaluations suggest that acceptance of unobtrusive in-home monitoring was closely tied to perceived utility of data generated by such systems [40].

Ubiquitous use of ICT devices in AD clinical trials have to overcome additional challenges. Verifying that a new methodology meets both internal (the measures really capture what they claim to capture) and external (use of a measure across different populations of interest, e.g., normal aging, Parkinson disease, and AD) validity is nontrivial. Additional confounders, most notably measuring degree of subject engagement in the intervention and the Hawthorne effect [41], also must be taken into consideration for designating best use of the data being collected.

Some of the common pitfalls in traditional neuropsychology testing, including sampling errors (data collected fails to capture specific cognitive domain of interest) and length of time required for data collection, require future work and analysis in the 
use of ICT devices. Integrating continuous data from ICT devices could help diagnose clinically significant events (related to moments of confusion, apathy and depression), which are often difficult to appreciate by clinical history and traditional neuropsychology tests alone. Being able to detect these events unobtrusively could provide a clinical window on the patient.

Despite potential benefits, use of ICT devices in AD clinical trials also faces significant challenges as the outcomes derived from pervasive computing approaches have not been well correlated with traditional neuropsychology measures. This could make the decision makers, including pharmaceutical companies and regulatory agencies, hesitant in interpreting patient outcome data collected by these devices. Related to this issue, the work by Hodges et al. [42] used sensor data gathered during a coffee-making task and correlated them with neuropsychological test scores in traumatic brain injury subjects. They found a positive correlation between sensor features and the first principal component of specific neuropsychological scores of interest. Work in a similar vein is warranted in the AD population to develop objective measures of comparison between longitudinal changes in neuropsychological test scores and activity or other functional markers. This could be a potential area of focus in the coming years as it is a significant unmet need.

\subsection{Future Directions of ICT Device Employment in AD Clinical Trials}

Future focus on monitoring cognitive domains using ICT devices could include the following:

\subsubsection{Language}

Low linguistic ability in young adulthood $[43,44]$ and low idea density later in life have been found to be associated with decline in cognitive function [45-47]. Studies have noted reduction in narrative discourse among patients with AD [48-50]. Measures of language function mirroring global progression through the successive clinical stages of $\mathrm{AD}$ have been reported [51-54].

\subsubsection{Motor Performance}

The 'brain-related common cause' hypothesis suggests that non-cognitive variables are related to cognitive variables because all have central nervous system involvement [55, 56]. In this light, measures of hand grip and walking speed are associated with the rate of cognitive decline [57-59]. Gait changes, including variability in speed, have been shown to predict MCI $[60,61]$. Slowing of walking speed has also been tied to the specific cognitive measure of processing speed $[62,63]$.

\subsubsection{Driving}

Even at the stage of MCI, individuals have less optimal driving performance and their driving abilities decline over time compared to cognitively normal individuals $[64,65]$. Testing performance on simulators [4] or data capture during real-time driving using ICT devices in cars could be an option to capture this everyday cognitive skill. 


\subsubsection{Eye Movements/saccades}

The anti-saccade task is a test of inhibitory control [66- 67]. Performance on this task is strongly correlated with neuropsychological tests of executive function in multiple diseases, including AD and Huntington's disease [69-71]. Eye wear with smart inserts are currently available that could be programmed to detect these changes, some of which are often performed at the bedside as a test of executive dysfunction [67].

\section{CONCLUSION}

Capturing early cognitive changes among populations vulnerable to AD will be of increasing interest in the coming decades. Identifying economically efficient ways of detecting functional and cognitive decline early in $\mathrm{AD}$ is a major challenge. Capturing cognitive and functional data in this population using ICT devices could successfully tackle this problem. Although current use of ICT devices in RCT for AD is poor and limited to actigraphy and accelerometer recordings, the next generation of ICT devices could help overcome the limitations of the long time interval between serial tests in traditional neuropsychology evaluation and detect functional decline in a subject's everyday context relative to the individual's baseline performance.

\section{CONFLICT OF INTEREST}

The authors indicated no potential conflicts of interest.

\section{REFERENCES}

[1] World Health Organization. WHO Mental Health Gap Action Programme (mhGAP) 2008. http://www.who.int/mental_health/mhgap/en/. Accessed September 09, 2014.

[2] Bateman RJ, Xiong C, Benzinger TL, Fagan AM, Goate A, Fox NC, et al. Clinical and biomarker changes in dominantly inherited Alzheimer's disease. N Engl J Med, 2012, 367(9):795-804.

[3] Pillai JA, Cummings JL. Clinical trials in predementia stages of Alzheimer disease. Med Clin North Am, 2013, 97(3):439-457.

[4] Silverberg NB, Ryan LM, Carrillo MC, Sperling R, Petersen RC, Posner HB, et al. Assessment of cognition in early dementia. Alzheimers Dement, 2011, 7(3):e60-e76.

[5] Robert PH, Konig A, Andrieu S, Bremond F, Chemin I, Chung PC, et al.Recommendations for ICT use in Alzheimer's disease assessment: Monaco CTAD Expert Meeting. J Nutr Health Aging, 2013, 17(8):653-660.

[6] Bassett SS, Folstein MF. Cognitive impairment and functional disability in the absence of psychiatric diagnosis. Psychol Med, 1991, 21: 77-84.

[7] Warren EJ, Grek A, Conn D. A correlation between cognitive performance and daily functioning in elderly people. J Geriatr Psychiatry Neurol, 1989, 2: 96-100.

[8] Moritz DJ, Kasl S, Berman LF. Cognitive functioning and the incidence of limitations in activities of daily living in an elderly community sample. Am J Epidemiol, 1995, 141: 41-49.

[9] Black S A,Rush RD. Cognitive and Functional Decline in Adults Aged 75 and Older. Journal of the American Geriatrics Society, 2002, 50: 1978-1986.

[10] McKhann GM, Knopman DS, Chertkow H, Hyman BT, Jack CR Jr, Kawas CH, Klunk WE, Koroshetz WJ, Manly JJ, Mayeux R, Mohs RC, Morris JC, Rossor MN, Scheltens P,Carrillo MC, Thies B, Weintraub S, Phelps CH. The diagnosis of dementia due to Alzheimer's disease: recommendations from the National Institute on Aging-Alzheimer's Association workgroups on diagnostic guidelines for Alzheimer's disease. Alzheimers Dement, 2011, 7(3):263-269. 
[11] Alwan M, Dalal S, Mack D, Kell SW, Turner B, Leachtenauer J, et al. Impact of monitoring technology in assisted living: outcome pilot. IEEE Trans Inf Technol Biomed, 2006, 10(1):192-198.

[12] Suzuki T, Murase S. Influence of outdoor activity and indoor activity on cognition decline: use of an infrared sensor to measure activity. Telemed J E Health, 2010, 16(6):686-690.

[13] Hayes TL, Abendroth F, Adami A, Pavel M, Zitzelberger TA, Kaye JA. Unobtrusive assessment of activity patterns associated with mild cognitive impairment. Alzheimers Dement, 2008, 4(6):395-405.

[14] Hayes TL, Larimer N, Adami A, Kaye JA. Medication adherence in healthy elders: small cognitive changes make a big difference. J Aging Health, 2009, 21(4):567-580.

[15] Kearns, W, Fozard, J, Nams, V, Craighead, J. Wireless telesurveillance system for detecting dementia. Gerontechnology, 2011, 10(2), 90-102.

[16] Kaye J, Mattek N, Dodge HH, Campbell I, Hayes T, Austin D, Hatt W, Wild K, Jimison H, Pavel M. Unobtrusive measurement of daily computer use to detect mild cognitive impairment. Alzheimers Dement, 2014, 10(1):10-17.

[17] Galambos C, Skubic M, Wang S, Rantz M. Management of Dementia and Depression Utilizing InHome Passive Sensor Data. Gerontechnology, 2013, 11(3):457-468.

[18] Dawadi PN, Cook DJ, Schmitter-Edgecombe M, Parsey C. Automated assessment of cognitive health using smart home technologies. Technol Health Care, 2013, 21(4):323-343.

[19] Hayes TL, Riley T, Mattek N, Pavel M, Kaye JA. Sleep habits in mild cognitive impairment. Alzheimer Dis Assoc Disord, 2014, 28(2):145-150.

[20] Scherder EJ, Van Someren EJ, Swaab DF. Transcutaneous electrical nerve stimulation (TENS) improves the rest-activity rhythm in midstage Alzheimer's disease. Behav Brain Res, 1999, 101(1):105-107.

[21] Ancoli-Israel S, Martin JL, Kripke DF, Marler M, Klauber MR. Effect of light treatment on sleep and circadian rhythms in demented nursing home patients. J Am Geriatr Soc, 2002, 50(2):282-289.

[22] Singer C, Tractenberg RE, Kaye J, Schafer K, Gamst A, Grundman M, et al. A multicenter, placebocontrolled trial of melatonin for sleep disturbance in Alzheimer's disease. Sleep, 2003, 26(7):893-901.

[23] Dowling GA, Hubbard EM, Mastick J, Luxenberg JS, Burr RL, Van Someren EJ. Effect of morning bright light treatment for rest-activity disruption in institutionalized patients with severe Alzheimer's disease. Int Psychogeriatr, 2005, 17(2):221-236.

[24] Dowling GA, Mastick J, Hubbard EM, Luxenberg JS, Burr RL. Effect of timed bright light treatment for rest-activity disruption in institutionalized patients with Alzheimer's disease. Int J Geriatr Psychiatry, 2005, 20(8):738-743.

[25] Ancoli-Israel S, Amatniek J, Ascher S, Sadik K, Ramaswamy K. Effects of galantamine versus donepezil on sleep in patients with mild to moderate Alzheimer disease and their caregivers: a doubleblind, head-to-head, randomized pilot study. Alzheimer Dis Assoc Disord, 2005, 19(4):240-245.

[26] Scherder EJ, van Tol MJ, Swaab DF. High-frequency cranial electrostimulation (CES) in patients with probable Alzheimer's disease. Am J Phys Med Rehabil, 2006, 85(7):614-618.

[27] Sloane PD, Williams CS, Mitchell CM, Preisser JS, Wood W, Barrick AL, et al. High-intensity environmental light in dementia: effect on sleep and activity. J Am Geriatr Soc, 2007, 55(10):1524-1533.

[28] Mahlberg R, Walther S, Eichmann U, Tracik F, Kunz D. Effects of rivastigmine on actigraphically monitored motor activity in severe agitation related to Alzheimer's disease: a placebo-controlled pilot study. Arch Gerontol Geriat, 2007, 45(1):19-26.

[29] Dowling GA, Burr RL, Van Someren EJ, Hubbard EM, Luxenberg JS, Mastick J, et al. Melatonin and bright-light treatment for rest-activity disruption in institutionalized patients with Alzheimer's disease. $J$ Am Geriatr Soc, 2008, 56(2):239-246.

[30] Gehrman PR, Connor DJ, Martin JL, Shochat T, Corey-Bloom J, Ancoli-Israel S. Melatonin fails to improve sleep or agitation in double-blind randomized placebo-controlled trial of institutionalized patients with Alzheimer disease. Am J Geriatr Psychiatry, 2009, 17(2):166-169. 
82 Review of Information and Communication Technology Devices for Monitoring Functional and Cognitive Decline in Alzheimer's Disease Clinical Trials

[31] Eggermont LH, Blankevoort CG, Scherder EJ. Walking and night-time restlessness in mild-tomoderate dementia: a randomized controlled trial. Age Ageing, 2010, 39(6):746-749.

[32] McCurry SM, Pike KC, Vitiello MV, Logsdon RG, Larson EB, Teri L. Increasing walking and bright light exposure to improve sleep in community-dwelling persons with Alzheimer's disease: results of a randomized, controlled trial. J Am Geriatr Soc, 2011, 59(8):1393-13402.

[33] Camargos EF, Louzada LL, Quintas JL, Naves JO, Louzada FM, Nobrega OT. Trazodone Improves Sleep Parameters in Alzheimer Disease Patients: A Randomized, Double-Blind, and PlaceboControlled Study. Am J Geriatr Psychiatry, 2014, 22(12):1565-1574.

[34] Hooghiemstra AM, Eggermont LH, Scheltens P, van der Flier WM, Bakker J, de Greef MH, et al. Study protocol: EXERcise and cognition in sedentary adults with early-ONset dementia (EXERCISEON). BMC Neurol, 2012, 12:75.20121275.

[35] Liu-Ambrose T, Eng JJ, Boyd LA, Jacova C, Davis JC, Bryan S, et al. Promotion of the mind through exercise (PROMoTE): a proof-of-concept randomized controlled trial of aerobic exercise training in older adults with vascular cognitive impairment. BMC Neurol, 2010, 10:14.

[36] Farran CJ, Staffileno BA, Gilley DW, McCann JJ, Yan L, Castro CM, et al. A lifestyle physical activity intervention for caregivers of persons with Alzheimer's disease. Am J Alzheimers Dis Other Demen, 2008, 23(2):132-142.

[37] Shoval N, Auslander GK, Freytag T, Landau R, Oswald F, Seidl U, et al. The use of advanced tracking technologies for the analysis of mobility in Alzheimer's disease and related cognitive diseases. BMC Geriatr, 2008, 8:7.

[38] Buchman AS, Boyle PA, Yu L, Shah RC, Wilson RS, Bennett DA. Total daily physical activity and the risk of AD and cognitive decline in older adults. Neurology, 2012, 78(17):1323-9.

[39] Ancoli-Israel S, Cole R, Alessi C, Chambers M, Moorcroft W, Pollak CP. The role of actigraphy in the study of sleep and circadian rhythms. Sleep, 2003, 26(3):342-392.

[40] Wild K, Boise L, Lundell J, Foucek A. Unobtrusive In-Home Monitoring of Cognitive and Physical Health: Reactions and Perceptions of Older Adults. J Appl Gerontol, 2008, 27(2):181-200.

[41] McCarney R, Warner J, Iliffe S, van Haselen R, Griffin M, Fisher P. The Hawthorne Effect: a randomised, controlled trial. BMC Med Res Methodol, 2007, 7:30.

[42] Hodges M, Kirsch N, Newman M, Pollack M.. Automatic assessment of cognitive impairment through electronic observation of object usage. Proceedings of the International Conference on Pervasive Computing; Springer-Verlag, Berlin, Heidelberg: 2010, 192-209.

[43] Snowdon DA, Kemper SJ, Mortimer JA, Greiner LH, Wekstein DR, Markesbery WR. Linguistic ability in early life and cognitive function and Alzheimer's disease in late life. Findings from the Nun Study. JAMA, 1996, 275(7):528-532.

[44] Kemper S, Greiner LH, Marquis JG, Prenovost K, Mitzner TL. Language decline across the life span: findings from the Nun Study. Psychol Agin, 2001, 16(2):227-239.

[45] Kintsch W, Keenan J. Reading rate and retention as a function of the number of propositions in the base structure of sentences. Cognit. Psychol, 1973, 5(3): 257-274.

[46] Farias ST, Chand V, Bonnici L, Baynes K, Harvey D, Mungas D, et al. Idea density measured in late life predicts subsequent cognitive trajectories: implications for the measurement of cognitive reserve. J Gerontol B Psychol Sci Soc Sci, 2012, 67(6):677-686.

[47] Kemper S, Marquis J, Thompson M. Longitudinal change in language production: effects of aging and dementia on grammatical complexity and propositional content. Psychol Aging, 2001, 16(4):600-614.

[48] Ehrlich JS, Obler LK, Clark L. Ideational and semantic contributions to narrative production in adults with dementia of the Alzheimer's type. J Commun Disord, 1997, 30(2):79-98.

[49] Feyereisen P, Berrewaerts J, Hupet M. Pragmatic skills in the early stages of Alzheimer's disease: an analysis by means of a referential communication task. Int J Lang Commun Disord, 2007, 42(1):1-17.

[50] Taler V, Phillips NA. Language performance in Alzheimer's disease and mild cognitive impairment: a comparative review. J Clin Exp Neuropsychol, 2008, 30(5):501-556. 
[51] Forbes-McKay KE, Venneri A. Detecting subtle spontaneous language decline in early Alzheimer's disease with a picture description task. Neurol Sci, 2005, 26(4):243-254.

[52] Oulhaj A, Wilcock GK, Smith AD, de Jager CA. Predicting the time of conversion to MCI in the elderly: role of verbal expression and learning. Neurology, 2009, 73(18):1436-1442.

[53] Ahmed S, Haigh AM, de Jager CA, Garrard P. Connected speech as a marker of disease progression in autopsy-proven Alzheimer's disease. Brain, 2013, 136(Pt 12):3727-3737.

[54] Chand V., Baynes K., Bonnici L., Farias S.T. Analysis of Idea Density (AID): A Manual. Department of Neurology, Center for Mind and Brain, Department of Linguistics, University of California. 2010.

[55] Christensen H, Mackinnon AJ, Korten A, Jorm AF. The "common cause hypothesis" of cognitive aging: evidence for not only a common factor but also specific associations of age with vision and grip strength in a cross-sectional analysis. Psychol Aging, 2001, 16(4):588-599.

[56] MacDonald SW, DeCarlo CA, Dixon RA. Linking biological and cognitive aging: toward improving characterizations of developmental time. J Gerontol B Psychol Sci Soc Sci, 2011,66 Suppl 1:i59-170.

[57] Alfaro-Acha A, Al Snih S, Raji MA, Kuo YF, Markides KS, Ottenbacher KJ. Handgrip strength and cognitive decline in older Mexican Americans. J Gerontol A Biol Sci Med Sci, 2006, 61(8):859-865.

[58] Boyle PA, Buchman AS, Wilson RS, Leurgans SE, Bennett DA. Association of muscle strength with the risk of Alzheimer disease and the rate of cognitive decline in community-dwelling older persons. Arch Neurol, 2009, 66(11):1339-1344.

[59] Verghese J, Robbins M, Holtzer R, Zimmerman M, Wang C, Xue X, et al. Gait dysfunction in mild cognitive impairment syndromes. J Am Geriatr Soc, 2008, 56(7):1244-1251.

[60] Buracchio T, Dodge HH, Howieson D, Wasserman D, Kaye J. The trajectory of gait speed preceding mild cognitive impairment. Arch Neurol, 2010, 67(8):980-986.

[61] Beauchet O, Allali G, Launay C, Herrmann FR, Annweiler C. Gait variability at fast-pace walking speed: a biomarker of mild cognitive impairment? J Nutr Health Aging, 2013, 17(3):235-239.

[62] Dodge HH, Mattek NC, Austin D, Hayes TL, Kaye JA. In-home walking speeds and variability trajectories associated with mild cognitive impairment. Neurology, 2012, 78(24):1946-1952.

[63] Welmer AK, Rizzuto D, Qiu C, Caracciolo B, Laukka EJ. Walking Speed, Processing Speed, and Dementia: A Population-Based Longitudinal Study. J Gerontol A Biol Sci Med Sci, 2014, 69(12): 1503-1510

[64] Duchek JM, Carr DB, Hunt L, Roe CM, Xiong C, Shah K, et al. Longitudinal driving performance in early-stage dementia of the Alzheimer type. J Am Geriatr Soc, 2003, 51(10):1342-1247.

[65] Ott BR, Heindel WC, Papandonatos GD, Festa EK, Davis JD, Daiello LA, et al. A longitudinal study of drivers with Alzheimer disease. Neurology, 2008, 70(14):1171-1178.

[66] Anderson TJ, MacAskill MR. Eye movements in patients with neurodegenerative disorders. Nat Rev Neurol, 2013, 9(2):74-85.

[67] Hellmuth J, Mirsky J, Heuer HW, Matlin A, Jafari A, Garbutt S, et al. Multicenter validation of a bedside antisaccade task as a measure of executive function. Neurology, 2012, 78(23):1824-1831.

[68] Munoz DP, Everling S. Look away: the anti-saccade task and the voluntary control of eye movement. Nat Rev Neurosci, 2004, 5(3):218-228.

[69] Ga rbutt S, Matlin A, Hellmuth J, Schenk AK, Johnson JK, Rosen H, et al. Oculomotor function in frontotemporal lobar degeneration, related disorders and Alzheimer's disease. Brain, 2008, 131 (Pt 5):1268-1281.

[70] Heuer HW, Mirsky JB, Kong EL, Dickerson BC, Miller BL, Kramer JH, et al. Antisaccade task reflects cortical involvement in mild cognitive impairment. Neurology, 2013, 81(14):1235-1243.

[71] Blekher T, Johnson SA, Marshall J, White K, Hui S, Weaver M, et al. Saccades in presymptomatic and early stages of Huntington disease. Neurology, 2006, 67(3):394-399. 



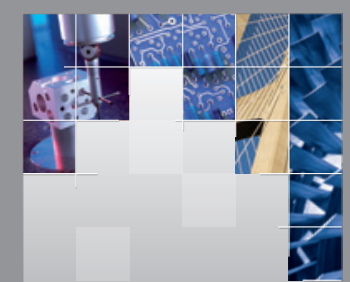

\section{Enfincering}
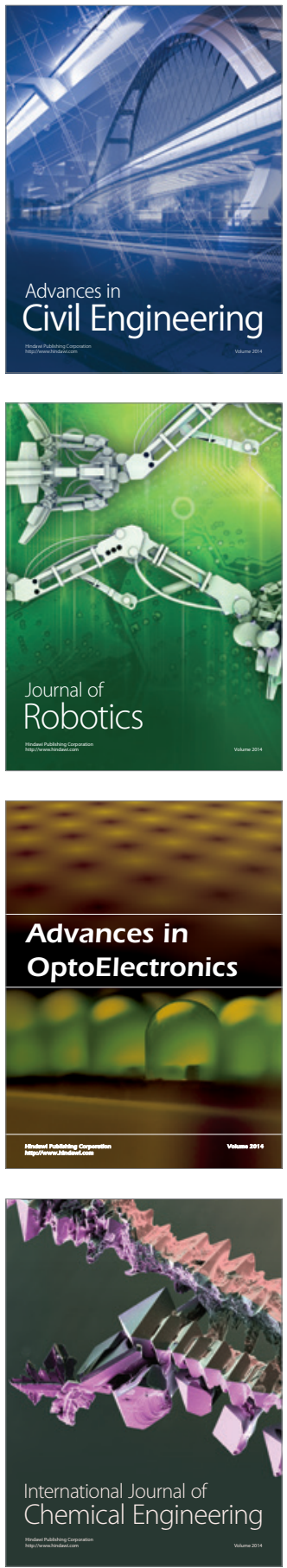

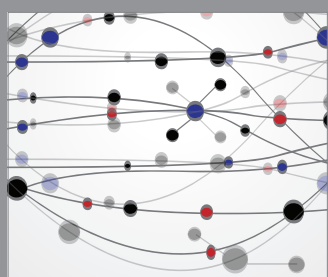

The Scientific World Journal

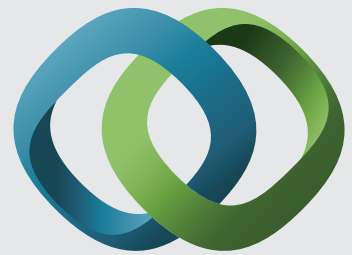

\section{Hindawi}

Submit your manuscripts at

http://www.hindawi.com
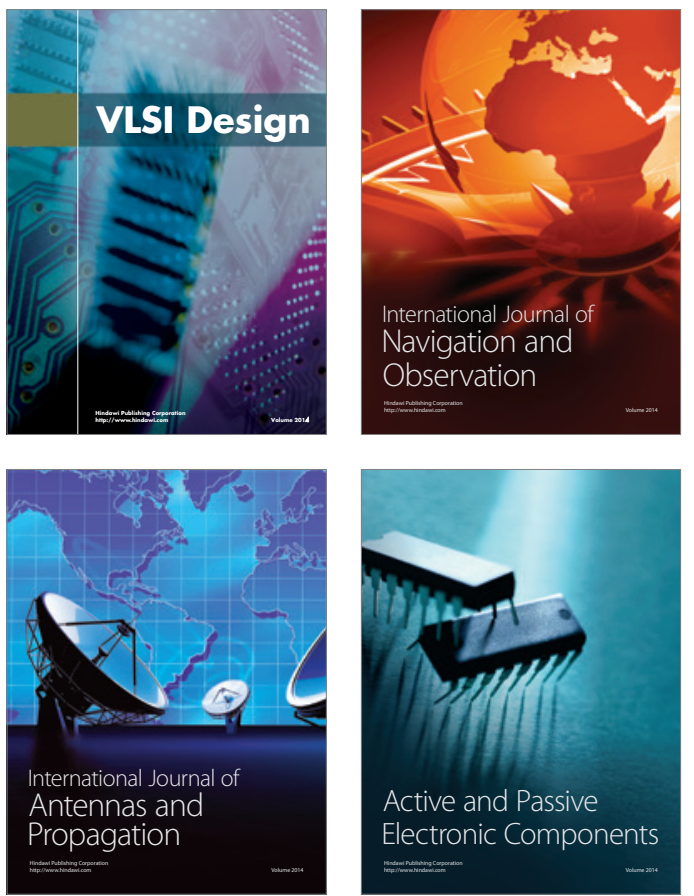
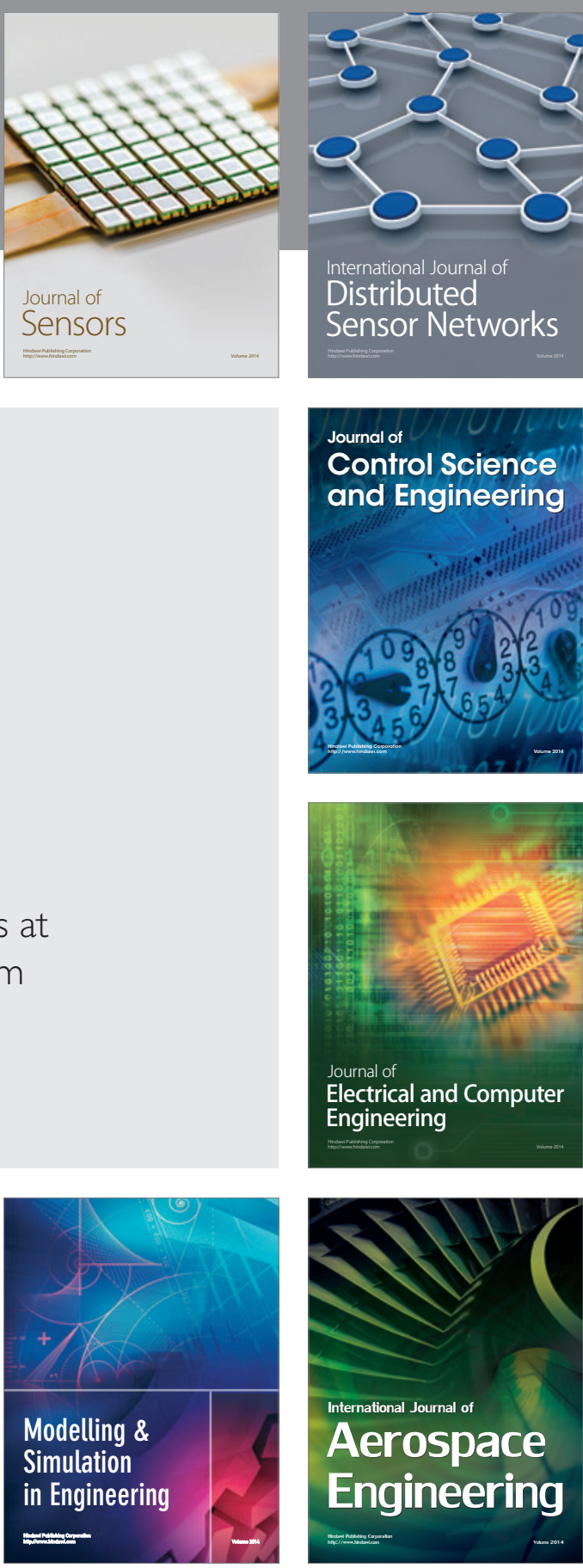

International Journal of

Distributed

Sensor Networks

Journal of

Control Science

and Engineering
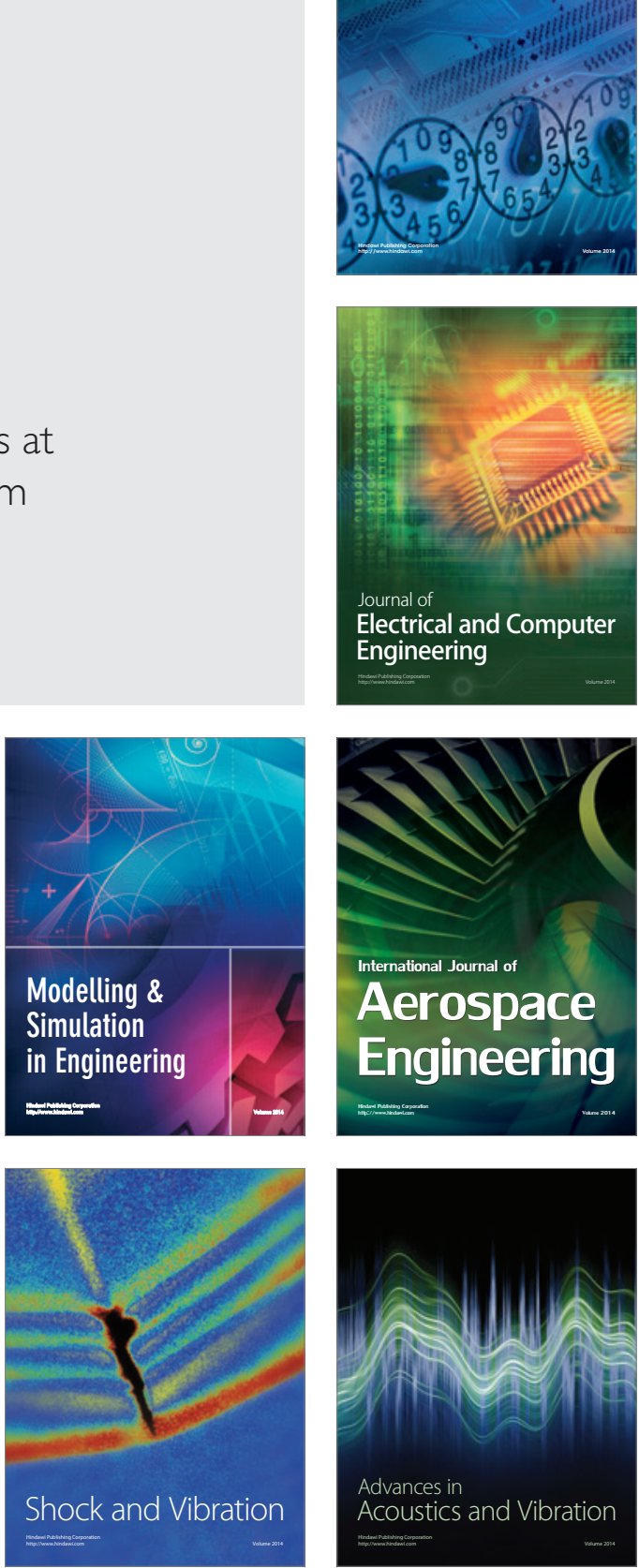